\title{
Variability in the production traits and nutritional efficiency of coffee cultivars when submitted to low soil nitrogen
}

\author{
W.M. Moura ${ }^{1}$, P.M.R. Cardoso ${ }^{2}$, G.A. Gravina ${ }^{3}$, V.S. Cavalcante ${ }^{1}$, \\ A.W. Pedrosa ${ }^{4}$ and T.C. Ferreira ${ }^{1}$ \\ ${ }^{1}$ Empresa de Pesquisa Agropecuária de Minas Gerais, EPAMIG Sudeste, \\ Viçosa, MG, Brasil \\ ${ }^{2}$ Universidade Federal de Viçosa, Viçosa, MG, Brasil \\ ${ }^{3}$ Universidade Estadual Norte Fluminense Darcy Ribeiro, Campos dos \\ Goytacazes, RJ, Brasil \\ ${ }^{4}$ Centro Universitário FACENS, Sorocaba, SP, Brasil \\ Corresponding author: W.M. Moura \\ E-mail: waldenia@epamig.ufv.br
}

Genet. Mol. Res. 18 (2): gmr18175

Received October 11, 2018

Accepted April 04, 2019

Published April 30, 2019

DOI http://dx.doi.org/10.4238/gmr18175

\begin{abstract}
Extensive use of nitrogen fertilizers in coffee crops increases production costs and environmental pollution. Developing cultivars more efficient in nitrogen $(\mathrm{N})$ utilization could contribute to reduce the need for $\mathrm{N}$ fertilization and promote sustainable production. We evaluated the variation in production characteristics among 20 coffee cultivars grown in nutrient solution with low $\mathrm{N}$ concentration $\left(1.0 \mathrm{mmol} . \mathrm{L}^{-1}\right)$, aiming to identify combinations to compose future populations to be used in breeding programs and obtain cultivars more efficient in $\mathrm{N}$ utilization. Morpho-agronomic traits and rooting, absorption, translocation, biomass production, and $\mathrm{N}$ utilization efficiencies were evaluated. The clustering methods Unweighted Pair Group Method with Arithmetic Mean (UPGMA) and canonical variables were employed. Cultivars presented differentiated responses at low $\mathrm{N}$ concentrations, except for nitrogen absorption efficiency. The UPGMA and canonical variables methods presented similar results, forming five cultivar clusters. Total dry mass contributed the most in the total dissimilarity. Significant genetic variability was detected among coffee cultivars grown at low N availability. Hybrids generated from cultivars Icatu Precoce 3282, Icatu Vermelho IAC 4045, and Acaiá Cerrado MG 1474 were found to be
\end{abstract}


the most promising to obtain a segregating population or heterotic hybrids, aiming at greater $\mathrm{N}$ utilization efficiency.

Key words: Coffea arabica; Nutritional efficiency; Plant breeding; Genetic variability

\section{INTRODUCTION}

Brazil is the largest coffee producer and exporter, accounting for approximately $35 \%$ of the world's production, with 56.47 million bags and a mean yield of 29.47 bags ha $^{-1}$ (2017/2018 harvest), cultivated in about 2.2 million ha (Conab, 2018). Coffee cultivation in low fertility soils has increased production costs due to the need for high doses of correctives and fertilizers, as high yields require proper plant nutrition. Nitrogen $(\mathrm{N})$ is the most demanded nutrient by coffee plants. Its deficiency limits the growth and production of coffee crops because it plays an essential role in leaf area expansion during plant growth and bean formation. Moreover, it affects the caffeine concentration in the phloem exudates (Gonthier et al., 2011; Reis et al., 2011; Neto et al., 2015).

The extensive application of nitrogen fertilizers to the crops aims at higher yields since varieties were selected under optimal $\mathrm{N}$ conditions. However, this fact does not imply in efficient $\mathrm{N}$ utilization (Kant, 2018). Most Brazilian coffee is grown in the Cerrado region, which often presents low levels of $\mathrm{N}$ in the soil. In order to supplement the low $\mathrm{N}$ content in the soil in these areas, about 600 to $800 \mathrm{~kg} \mathrm{ha}^{-1}$ of nitrogen fertilizer is generally used for growing coffee. These doses are far above the traditional recommendations of 150 to $450 \mathrm{~kg} \mathrm{ha}^{-1}$ of nitrogen fertilizer. This practise substantially increases the cost of production for the coffee grower by more than two times, and often does not provide a proportional increase in yield (Bruno est al., 2015).

Usually, the $\mathrm{N}$ recovery efficiency is lower than $50 \%$ in plants cultivated under adequate $\mathrm{N}$ conditions due to losses by volatilization, denitrification, leaching, soil erosion, and biotic and abiotic stresses, resulting in high fertilization costs, along with environmental pollution (Fageria et al., 2008). The species of a given crop and the genotypes of a given species have significant variation in nutrient utilization and absorption efficiency. The determination of the nutrient utilization efficiency allows the differentiation of plant genotypes and cultivars by the ability to use and absorb nutrients for maximum dry mass production (Baligar and Fageria, 2015).

Some coffee varieties behave distinctly in relation to nutritional characteristics when cultivated under the same conditions, resulting in divergent growth and yield responses. Some researchers have reported the genetic differences between cultivars regarding nutrient absorption, transport, and utilization efficiencies (Tomaz et al., 2008; Amaral et al., 2012; Pedrosa et al., 2013; Martins et al., 2015). However, these studies did not evaluate the nutritional efficiency of coffee cultivars grown under low $\mathrm{N}$ availability, nor did they use the clustering methods UPGMA and canonical variables to separate cultivars into clusters, aiming at improved crosses.

The different behavior of cultivars grown under stress enables selecting distinct individuals, aiming at obtaining greater variability. Crosses involving genetically divergent parents are the most convenient to produce a greater heterotic effect in the progeny and presents a higher probability of obtaining genetic variability in segregating generations (Falconer, 1981).

The selection of more adapted coffee cultivars for environments with low $\mathrm{N}$ concentration will contribute to the advancement of breeding programs by the development of 
more nutrient-efficient plants. This fact can lead to higher coffee yields and lower nitrogen fertilizers application, reducing costs with chemical fertilizers. In this context, for the evaluation of coffee cultivars under nitrogen deficiency conditions, we hypothesize the existence of combinations between cultivars that present greater genetic variability, which results in a segregating population or heterotic hybrids.

To this end, we evaluated the genetic divergence among 20 coffee cultivars grown at low $\mathrm{N}$ concentration $\left(1.0 \mathrm{mmol} . \mathrm{L}^{-1}\right)$, aiming at identifying promising combinations for breeding programs.

\section{MATERIAL AND METHODS}

The experiment was carried out by Empresa de Pesquisa Agropecuária de Minas Gerais/Sudeste (EPAMIG Sudeste), in a greenhouse with a rectilinear glass ceiling of the Plant Science Department of the Federal University of Viçosa, Minas Gerais. During the experiment the greenhouse presented average day and night temperatures of $33^{\circ} \mathrm{C} \pm 1$ and $25^{\circ} \mathrm{C} \pm 1$, respectively, and an average relative humidity of $40 \%$. The local climate according to the classification of Koppen is Cwa, defined as humid subtropical climate with hot summer and dry winter. The experiment was conducted during the period between winter and summer.

Twenty cultivars of arabica coffee (Table 1), being 18 commercial (comprising traditionally grown in the main coffee regions of Brazil, and new cultivars recently launched on the market) and two tradtional cultivars (San Ramon and São Bernardo). These cultivars presented variations in morphoagronomic traits, such as productivity, drink quality, resistance to diseases and pests. In addition, they have been developed in breeding programs to be grown under appropriate soil fertility conditions, unlike the old cultivars. Some of these have already been evaluated under conditions of nutritional stress for various nutrients.

Table 1. Genealogy of the Coffea arabica cultivars.

\begin{tabular}{ll}
\hline Cultivars & Genealogy \\
\hline${ }^{2}$ Catuaí Amarelo IAC 62 & Caturra Amarelo IAC 476-11 x Mundo Novo IAC 374-19 \\
${ }^{1}$ Paraíso MG H 419-1 & Caturra Amarelo IAC 30 x Híbrido de Timor UFV 445-46 \\
${ }^{2}$ Icatu Vermelho IAC 4045 & Coffea canephora x Bourbon Vermelho \\
${ }^{2}$ Obatã IAC 1669/20 & Villa Sarchi x Híbrido de Timor \\
${ }^{4}$ Caturra Amarelo & Mutação do Caturra Vermelho \\
${ }^{3}$ IPR 102 & Icatu x (Catuaí Amarelo IAC 66 x Catuaí Vermelho IAC 99) \\
${ }^{1}$ Catuaí Vermelho IAC 15 & Caturra Amarelo IAC 476-11 x Mundo Novo \\
${ }^{1}$ Rubi MG 1192 & Catuaí x Mundo Novo \\
${ }^{3}$ IPR 103 & Icatu x (Catuaí Amarelo IAC 66 x Catuaí Vermelho IAC 99) \\
${ }^{1}$ Araponga MG1 & Caturra Amarelo IAC 86 x Híbrido de Timor UFV 446-08 \\
${ }^{1}$ Topázio MG 1190 & Catuaí Amarelo x Novo Mundo \\
${ }^{4}$ San Ramon & Progênie C 1034-4 Introdução da Costa Rica \\
${ }^{2}$ Icatu Precoce 3282 & Icatu Vermelho x Bourbon Amarelo \\
${ }^{2}$ Tupi IAC 1669-33 & Villa Sarchi x Híbrido de Timor \\
${ }^{4}$ Catucaí 785/15 & Icatu Vermelho x Catuaí Vermelho \\
${ }^{1}$ Acaiá Cerrado MG 1474 & Seleção de Mundo Novo \\
${ }^{1}$ Oeiras MG 6851 & Híbrido CIFC HW 26/5 (Caturra Vermelho x Híbrido de Timor) \\
${ }^{2}$ São Bernardo & Mutação Típica do Café \\
${ }^{1}$ Pau Brasil MG1 & Catuaí Vermelho IAC 15 x Híbrido de Timor UFV 442/34 \\
${ }^{4}$ Caturra Vermelho & Mutação de Bourbon Vermelho \\
${ }^{1}$ EPAMIG; ${ }^{2}$ Instituto Agronômico de Campinas - IAC; ${ }^{3}$ Instituto Agronômico do Paraná - IAPAR e ${ }^{4}$ Fundação \\
PROCAFE, institutions of origin of cultivars.
\end{tabular}


The cultivars were cultivated in an aerated nutrient solution containing low $\mathrm{N}$ concentration $\left(1.0 \mathrm{mmol} . \mathrm{L}^{-1}\right)$. This amount nitrogen was based on the results obtained for dry matter production in increasing doses of $\mathrm{N}$ (Caixeta et al., 2004). The experiment consisted of a randomized complete block design, with three replications. Each plot comprised one pot with two plants cultivated in nutrient solution.

The seeds of the cultivars were germinated in a sand bed previously disinfected with $\mathrm{HCl} 0.1 \mathrm{~mol}_{\mathrm{dm}} \mathrm{-}^{-3}$ and transplanted at the cotyledon leaf stage ("jaguar ear"), at 120 days after sowing, to polypropylene pots containing 8.0 L of modified Hoagland and Arnon (1950) nutrient solution that was static aerated, with two plants per pot. The nutrient solution was modified to provide a low concentration of $\mathrm{N}\left(1.0 \mathrm{mmol} . \mathrm{L}^{-1}\right)$, thus simulating what would happen in the soil. Nitrogen was supplied as $\mathrm{KNO}_{3}$. Volumes of nutrient solution added to the pots were completed weekly with deionized water, and the $\mathrm{pH}$ was adjusted with $\mathrm{HCl} 0.1 \mathrm{~mol}^{-\mathrm{dm}^{-3}}$ and $\mathrm{NaOH} 0.1$ mol.dm ${ }^{-3}$ to between 5.5 and 6.5. The nutrient solution was changed based on the electrical conductivity (EC), whenever its depletion reached $30 \%$ of the initial EC.

The were harvested 168 days after transplantation of the seedlings to the vessels. The following traits were evaluated: plant height $(\mathrm{PH}, \mathrm{cm})$, measured from the base of the orthotropic branch to the apex of the plant; stem diameter (SD, $\mathrm{mm}$ ), measured at $5 \mathrm{~cm}$ from the base of the stem, using a caliper; number of nodes (NNO), obtained by visual counting of nodes in the orthotropic branch; internode length (IL, cm), calculated by the plant height/number of nodes ratio; number of leaf pairs (NLP), obtained by counting the leaf pairs in the whole plant; leaf area $\left(\mathrm{LA}, \mathrm{cm}^{2}\right)$, quantified after harvest, using an AT Delta-T Devices area meter.

Afterward, plants were collected and separated (into root, stem, and leaves), stored in paper bags, and dried in a forced air circulation oven at $70^{\circ} \mathrm{C}$, for $72 \mathrm{~h}$. Then, the plant material was weighed to determine root dry mass (RDM), stem dry mass (SDM), leaf dry mass (LDM), shoot dry mass $($ SHDM $=$ sum of LDM and SDM), total dry mass $($ TDM $=$ sum of SHDM and $\mathrm{RDM}$ ), and root/shoot dry mass ratio (RSDM). The dry plant material was ground in a Willey mill with 20 mesh sieve, where samples were taken to determine the nitrogen contents, according to Embrapa (2009). The $\mathrm{N}$ content was obtained by the product between the nutrient contents and the dry mass of the different parts of the plant.

The nutritional efficiency indices were estimated considering the dry mass production and $\mathrm{N}$ content, according to the methodology described by Siddiqi and Glass (1981) and Bailian et al. (1991): Rooting Efficiency $\left(\mathrm{RE}, \mathrm{g}^{2} \cdot \mathrm{mg}^{-1}\right)=(\text { root dry mass })^{2} /$ total $\mathrm{N}$ in the plant; nitrogen absorption efficiency (NAE, mg. $\mathrm{g}^{-1}$ ) $=$ total $\mathrm{N}$ in the plant / root dry mass; nitrogen translocation efficiency $\left(\mathrm{NTE}, \mathrm{mg} \cdot \mathrm{g}^{-1}\right)=\mathrm{N}$ in the shoots/total $\mathrm{N}$ in the plant; nitrogen utilization efficiency $\left(\mathrm{NUE}, \mathrm{g}^{2} \cdot \mathrm{mg}^{-1}\right)=\left(\right.$ total dry mass) ${ }^{2} /$ total $\mathrm{N}$ in the plant; biomass production efficiency (BPE, $\left.\mathrm{g}^{2} \cdot \mathrm{mg}^{-1}\right)=(\text { shoot dry mass })^{2} / \mathrm{N}$ in the shoots.

Data were subject to univariate analysis of variance, and the means were clustered by the Scott-Knott's test at 5\% probability level. The Unweighted Pair-Group Method Using Arithmetic Averages (UPGMA), based on the genetic dissimilarity matrix estimated by the Mahalanobis' Generalized Distance, and the method of Canonic Variables were used for the multivariate analyses. The relative importance of the evaluated traits was calculated by the method of Singh (Singh, 1981). Analyses were performed using the GENES software (Cruz, 2013) and the hcluster package of the R software (R Development Core Team, 2006).

\section{RESULTS}

Coffee cultivars showed significant differences for most of the traits evaluated ( $\mathrm{P} \leq$ 0.05) (Tables 2 and 3). 
Cultivars showed similar behaviors (Table 2) for plant height and internode length. The highest means for these traits were observed for cultivars Icatu Vermelho IAC 4045, Icatu Precoce 3282, and Acaiá Cerrado MG 1474, while the lowest means were detected for cultivars San Ramon and São Bernardo. These five cultivars had the lowest values for leaf area, with a mean of $76 \mathrm{dm}^{2}$.

Table 2. Plant height (PH), internode length (IL), number of nodes (NNO), number of leaf pairs (NLP), leaf area (LA), stem diameter (SD), root dry mass (RDM), and stem dry mass (SDM) evaluated in coffee cultivars grown in nutrient solution at low nitrogen concentration $\left(1.0 \mathrm{mmol} . \mathrm{L}^{-1}\right)$.

\begin{tabular}{|c|c|c|c|c|c|c|c|c|}
\hline Cultivars & PH & IL & $\begin{array}{c}\mathbf{L A} \\
--\mathbf{d m}^{2}--\end{array}$ & NNO & NLP & $\begin{array}{c}\text { SD } \\
---m m--\end{array}$ & \multicolumn{2}{|c|}{-------g-------- } \\
\hline Icatu Vermelho IAC 4045 & $42.7 \mathrm{~A}$ & $4.4 \mathrm{~A}$ & $84.3 \mathrm{~B}$ & $9.7 \mathrm{~A}$ & $8.7 \mathrm{~A}$ & $44.2 \mathrm{~A}$ & $1.8 \mathrm{C}$ & $1.9 \mathrm{~A}$ \\
\hline Icatu Precoce 3282 & $42.2 \mathrm{~A}$ & $4.6 \mathrm{~A}$ & $86.5 \mathrm{~B}$ & $9.2 \mathrm{~A}$ & $8.2 \mathrm{~B}$ & $46.7 \mathrm{~A}$ & $1.4 \mathrm{C}$ & $2.0 \mathrm{~A}$ \\
\hline Acaiá Cerrado MG 1474 & $43.7 \mathrm{~A}$ & $4.4 \mathrm{~A}$ & $83.2 \mathrm{~B}$ & $9.8 \mathrm{~A}$ & $8.8 \mathrm{~A}$ & $45.2 \mathrm{~A}$ & $1.5 \mathrm{C}$ & $2.1 \mathrm{~A}$ \\
\hline Catucaí Vermelho 785/15 & $29.5 \mathrm{~B}$ & $3.0 \mathrm{~B}$ & $113.9 \mathrm{~A}$ & $9.8 \mathrm{~A}$ & $8.8 \mathrm{~A}$ & $49.3 \mathrm{~A}$ & $2.4 \mathrm{~B}$ & $2.1 \mathrm{~A}$ \\
\hline Catuaí Amarelo IAC 62 & $30.3 \mathrm{~B}$ & $3.2 \mathrm{~B}$ & $104.8 \mathrm{~A}$ & $9.5 \mathrm{~A}$ & $8.5 \mathrm{~B}$ & $45.7 \mathrm{~A}$ & $1.8 \mathrm{C}$ & $1.9 \mathrm{~A}$ \\
\hline Paraíso MG H 419-1 & $28.2 \mathrm{~B}$ & $3.1 \mathrm{~B}$ & $101.1 \mathrm{~A}$ & $9.0 \mathrm{~B}$ & $8.0 \mathrm{C}$ & $40.2 \mathrm{~B}$ & $2.1 \mathrm{~B}$ & $1.5 \mathrm{~B}$ \\
\hline Obatã IAC 1669/20 & $28.7 \mathrm{~B}$ & $3.2 \mathrm{~B}$ & $115.8 \mathrm{~A}$ & $8.8 \mathrm{~B}$ & $7.8 \mathrm{C}$ & $51.5 \mathrm{~A}$ & $2.9 \mathrm{~A}$ & $1.8 \mathrm{~A}$ \\
\hline Caturra Amarelo & $28.3 \mathrm{~B}$ & $3.1 \mathrm{~B}$ & $99.7 \mathrm{~A}$ & $9.2 \mathrm{~A}$ & $8.2 \mathrm{~B}$ & $50.2 \mathrm{~A}$ & $2.3 \mathrm{~B}$ & $1.6 \mathrm{~B}$ \\
\hline IPR 102 & $26.2 \mathrm{~B}$ & $3.3 \mathrm{~B}$ & $104.4 \mathrm{~A}$ & $8.0 \mathrm{C}$ & $7.0 \mathrm{D}$ & $51.8 \mathrm{~A}$ & $2.5 \mathrm{~B}$ & $1.5 \mathrm{~B}$ \\
\hline Catuaí Vermelho IAC 15 & $29.5 \mathrm{~B}$ & $3.0 \mathrm{~B}$ & $96.9 \mathrm{~A}$ & $9.8 \mathrm{~A}$ & $8.8 \mathrm{~A}$ & $46.2 \mathrm{~A}$ & $2.2 \mathrm{~B}$ & $1.5 \mathrm{~B}$ \\
\hline Rubi MG 1192 & $28.9 \mathrm{~B}$ & $2.9 \mathrm{~B}$ & $94.6 \mathrm{~A}$ & $10.0 \mathrm{~A}$ & $9.0 \mathrm{~A}$ & $44.3 \mathrm{~A}$ & $1.9 \mathrm{C}$ & $1.6 \mathrm{~B}$ \\
\hline IPR 103 & $27.9 \mathrm{~B}$ & $3.2 \mathrm{~B}$ & $109.0 \mathrm{~A}$ & $8.7 \mathrm{~B}$ & $7.7 \mathrm{C}$ & $48.8 \mathrm{~A}$ & $2.2 \mathrm{~B}$ & $1.6 \mathrm{~B}$ \\
\hline Araponga MG1 & $32.2 \mathrm{~B}$ & $3.4 \mathrm{~B}$ & $113.7 \mathrm{~A}$ & $9.3 \mathrm{~A}$ & $8.3 \mathrm{~B}$ & $50.0 \mathrm{~A}$ & $2.7 \mathrm{~A}$ & $2.0 \mathrm{~A}$ \\
\hline Topázio MG 1190 & $30.9 \mathrm{~B}$ & $3.2 \mathrm{~B}$ & $110.8 \mathrm{~A}$ & $9.7 \mathrm{~A}$ & $8.7 \mathrm{~A}$ & $51.0 \mathrm{~A}$ & $2.5 \mathrm{~B}$ & $1.8 \mathrm{~A}$ \\
\hline San Ramon & 14.8 D & $1.7 \mathrm{D}$ & $55.0 \mathrm{~B}$ & $8.8 \mathrm{~B}$ & $7.8 \mathrm{C}$ & $28.3 \mathrm{C}$ & $1.0 \mathrm{C}$ & $0.5 \mathrm{C}$ \\
\hline Tupi IAC 1669-33 & $27.8 \mathrm{~B}$ & $3.5 \mathrm{~B}$ & $120.4 \mathrm{~A}$ & $8.0 \mathrm{C}$ & $7.0 \mathrm{D}$ & $57.3 \mathrm{~A}$ & $3.0 \mathrm{~A}$ & $2.1 \mathrm{~A}$ \\
\hline Oeiras MG 6851 & $29.1 \mathrm{~B}$ & $3.4 \mathrm{~B}$ & $95.1 \mathrm{~A}$ & $8.7 \mathrm{~B}$ & $7.7 \mathrm{C}$ & $43.5 \mathrm{~A}$ & $1.5 \mathrm{C}$ & $1.4 \mathrm{~B}$ \\
\hline São Bernardo & $21.0 \mathrm{C}$ & $2.3 \mathrm{C}$ & $70.1 \mathrm{~B}$ & $9.2 \mathrm{~A}$ & $8.2 \mathrm{~B}$ & $35.7 \mathrm{~B}$ & $1.5 \mathrm{C}$ & $0.8 \mathrm{C}$ \\
\hline Pau Brasil MG1 & $30.3 \mathrm{~B}$ & $3.4 \mathrm{~B}$ & $103.4 \mathrm{~A}$ & $8.8 \mathrm{~B}$ & $7.8 \mathrm{C}$ & $48.0 \mathrm{~A}$ & $2.2 \mathrm{~B}$ & $1.7 \mathrm{~B}$ \\
\hline Caturra Vermelho & $29.1 \mathrm{~B}$ & $3.1 \mathrm{~B}$ & $92.4 \mathrm{~A}$ & $9.5 \mathrm{~A}$ & $8.7 \mathrm{~A}$ & $47.5 \mathrm{~A}$ & $1.7 \mathrm{C}$ & $1.6 \mathrm{~B}$ \\
\hline Mean & 30.1 & 3.3 & 97.7 & 9.2 & 8.2 & 46.3 & 2.1 & 1.6 \\
\hline $\mathrm{CV}(\%)$ & 10.8 & 9.4 & 15.6 & 4.1 & 4.6 & 18.9 & 21.7 & 19.3 \\
\hline
\end{tabular}

*Means followed by the same letters in the columns do not differ from each other by the Scott-Knot's test, at $5 \%$ probability level.

Regarding the number of nodes and number of leaf pairs in the orthotropic branches (Table 2), cultivars were classified into three and four clusters, respectively. Cultivars Icatu Vermelho IAC 4045, Acaiá Cerrado MG 1474, Catucaí Vermelho 785/15, Catuaí Vermelho IAC 15, Rubi MG 1192, Topázio MG 1190, and Caturra Vermelho were allocated in the clusters with the highest means for both traits. Conversely, cultivars IPR 102 and Tupi IAC 1669-33 remained in the cluster with the lowest means for both traits. Similar to number of nodes, stem diameter also formed three clusters. The clusters with the highest and intermediate means were composed of 85 and $10 \%$ of the cultivars, respectively, while the cluster with the lowest mean was composed only of cultivar San Ramon.

Cultivars Obatã IAC 1669/20, Araponga MG1, and Tupi IAC presented the highest root and stem dry mass, concomitantly. Conversely, São Bernardo and San Ramon presented the lowest means for these traits (Table 2).

Regarding shoot dry mass and total dry mass, cultivars Catucaí Vermelho 785/15, Obatã IAC 1669/20, IPR 102, IPR 103, Araponga MG 1, Topázio MG 1190, and Tupi IAC 1669-33 were the most productive (Table 3). Again, the cultivars San Ramon and São Bernardo had the lowest means. 
Table 3. Shoot dry mass (SHDM), total dry mass (TDM), root/shoot dry mass ratio (RSDM), nitrogen absorption efficiency (NAE), nitrogen translocation efficiency (NTE), rooting efficiency (RE), nitrogen utilization efficiency (NUE), and biomass production efficiency (BPE) evaluated in coffee cultivars grown in nutrient solution at low nitrogen concentration $\left(1.0 \mathrm{mmol} . \mathrm{L}^{-1}\right)$.

\begin{tabular}{|c|c|c|c|c|c|c|c|c|}
\hline \multirow[t]{2}{*}{ Cultivars } & SHDM & TDM & \multirow{2}{*}{$\begin{array}{l}\text { RSDM } \\
\text {-g.g }{ }^{-1} \text { - }\end{array}$} & NAE & NTE & \multirow[t]{2}{*}{$\mathbf{R E}$} & NUE & \multirow[t]{2}{*}{ BPE } \\
\hline & \multicolumn{2}{|c|}{------ g ------ } & & \multicolumn{2}{|c|}{--- mg.mg ${ }^{-1}$-.- } & & $g^{2} \cdot m^{-1}-$ & \\
\hline Icatu Vermelho IAC 4045 & $5.9 \mathrm{~A}$ & $7.7 \mathrm{~B}$ & $0.31 \mathrm{~A}$ & 75.9 & $0.85 \mathrm{~A}$ & $0.026 \mathrm{C}$ & $0.45 \mathrm{~B}$ & $0.31 \mathrm{~B}$ \\
\hline Icatu Precoce 3282 & $6.4 \mathrm{~A}$ & $7.9 \mathrm{~B}$ & $0.22 \mathrm{~B}$ & 108.7 & $0.86 \mathrm{~A}$ & $0.014 \mathrm{C}$ & $0.42 \mathrm{~B}$ & $0.32 \mathrm{~B}$ \\
\hline Acaiá Cerrado MG 1474 & $6.2 \mathrm{~A}$ & $7.7 \mathrm{~B}$ & $0.24 \mathrm{~B}$ & 107.5 & $0.84 \mathrm{~A}$ & $0.016 \mathrm{C}$ & $0.39 \mathrm{~B}$ & $0.29 \mathrm{~B}$ \\
\hline Catucaí Vermelho 785/15 & $8.3 \mathrm{~A}$ & $10.7 \mathrm{~A}$ & $0.29 \mathrm{~B}$ & 82.4 & $0.81 \mathrm{~B}$ & $0.030 \mathrm{~B}$ & $0.59 \mathrm{~A}$ & $0.44 \mathrm{~A}$ \\
\hline Catuaí Amarelo IAC 62 & $6.8 \mathrm{~A}$ & $8.6 \mathrm{~B}$ & $0.28 \mathrm{~B}$ & 91.8 & $0.80 \mathrm{~B}$ & $0.022 \mathrm{C}$ & $0.45 \mathrm{~B}$ & $0.35 \mathrm{~B}$ \\
\hline Paraíso MG H 419-1 & $6.3 \mathrm{~A}$ & $8.4 \mathrm{~B}$ & $0.33 \mathrm{~A}$ & 78.3 & $0.78 \mathrm{C}$ & $0.028 \mathrm{~B}$ & $0.44 \mathrm{~B}$ & $0.31 \mathrm{~B}$ \\
\hline Obatã IAC 1669/20 & $7.6 \mathrm{~A}$ & $10.5 \mathrm{~A}$ & $0.39 \mathrm{~A}$ & 66.1 & $0.75 \mathrm{C}$ & $0.045 \mathrm{~A}$ & $0.57 \mathrm{~A}$ & $0.40 \mathrm{~A}$ \\
\hline Caturra Amarelo & $6.6 \mathrm{~A}$ & $8.8 \mathrm{~B}$ & $0.35 \mathrm{~A}$ & 73.2 & $0.78 \mathrm{C}$ & $0.032 \mathrm{~B}$ & $0.48 \mathrm{~B}$ & $0.33 \mathrm{~B}$ \\
\hline IPR 102 & $6.8 \mathrm{~A}$ & $9.3 \mathrm{~A}$ & $0.37 \mathrm{~A}$ & 74.8 & $0.75 \mathrm{C}$ & $0.034 \mathrm{~B}$ & $0.46 \mathrm{~B}$ & $0.33 \mathrm{~B}$ \\
\hline Catuaí Vermelho IAC 15 & $6.2 \mathrm{~A}$ & $8.3 \mathrm{~B}$ & $0.35 \mathrm{~A}$ & 77.3 & $0.78 \mathrm{C}$ & $0.030 \mathrm{~B}$ & $0.43 \mathrm{~B}$ & $0.30 \mathrm{~B}$ \\
\hline Rubi MG 1192 & $6.3 \mathrm{~A}$ & $8.3 \mathrm{~B}$ & $0.32 \mathrm{~A}$ & 81.9 & $0.80 \mathrm{~B}$ & $0.025 \mathrm{C}$ & $0.43 \mathrm{~B}$ & $0.31 \mathrm{~B}$ \\
\hline IPR 103 & $7.0 \mathrm{~A}$ & $9.2 \mathrm{~A}$ & $0.32 \mathrm{~A}$ & 81.7 & $0.80 \mathrm{~B}$ & $0.028 \mathrm{~B}$ & $0.48 \mathrm{~B}$ & $0.34 \mathrm{~B}$ \\
\hline Araponga MG 1 & $7.7 \mathrm{~A}$ & $10.5 \mathrm{~A}$ & $0.36 \mathrm{~A}$ & 70.6 & $0.76 \mathrm{C}$ & $0.040 \mathrm{~A}$ & $0.57 \mathrm{~A}$ & $0.41 \mathrm{~A}$ \\
\hline Topázio MG 1190 & $7.3 \mathrm{~A}$ & $9.8 \mathrm{~A}$ & $0.34 \mathrm{~A}$ & 72.1 & $0.79 \mathrm{C}$ & $0.036 \mathrm{~B}$ & $0.55 \mathrm{~A}$ & $0.39 \mathrm{~A}$ \\
\hline San Ramon & $3.2 \mathrm{~B}$ & $4.2 \mathrm{C}$ & $0.31 \mathrm{~A}$ & 118.6 & $0.82 \mathrm{~B}$ & $0.008 \mathrm{C}$ & $0.15 \mathrm{C}$ & $0.11 \mathrm{C}$ \\
\hline Tupi IAC 1669-33 & $8.0 \mathrm{~A}$ & $11.1 \mathrm{~A}$ & $0.38 \mathrm{~A}$ & 62.0 & $0.74 \mathrm{C}$ & $0.050 \mathrm{~A}$ & $0.65 \mathrm{~A}$ & $0.46 \mathrm{~A}$ \\
\hline Oeiras MG 6851 & $6.2 \mathrm{~A}$ & $7.7 \mathrm{~B}$ & $0.24 \mathrm{~B}$ & 114.9 & $0.84 \mathrm{~A}$ & $0.014 \mathrm{C}$ & $0.36 \mathrm{~B}$ & $0.28 \mathrm{~B}$ \\
\hline São Bernardo & $4.2 \mathrm{~B}$ & $5.7 \mathrm{C}$ & $0.34 \mathrm{~A}$ & 98.8 & $0.81 \mathrm{~B}$ & $0.016 \mathrm{C}$ & $0.24 \mathrm{C}$ & $0.16 \mathrm{C}$ \\
\hline Pau Brasil MG 1 & $5.9 \mathrm{~A}$ & $8.1 \mathrm{~B}$ & $0.39 \mathrm{~A}$ & 74.6 & $0.76 \mathrm{C}$ & $0.033 \mathrm{~B}$ & $0.42 \mathrm{~B}$ & $0.29 \mathrm{~B}$ \\
\hline Caturra Vermelho & $6.3 \mathrm{~A}$ & $8.0 \mathrm{~B}$ & $0.27 \mathrm{~B}$ & 89.5 & $0.84 \mathrm{~A}$ & $0.020 \mathrm{C}$ & $0.43 \mathrm{~B}$ & $0.32 \mathrm{~B}$ \\
\hline Mean & 6.5 & 9.0 & 0.32 & 85.0 & 0.80 & 0.031 & 0.45 & 0.32 \\
\hline $\mathrm{CV}(\%)$ & 16.2 & 15.8 & 19.2 & 21.8 & 3.54 & 40.3 & 18.4 & 18.2 \\
\hline
\end{tabular}

* Means followed by the same letters in the columns do not differ from each other by the Scott-Knot's test, at $5 \%$ probability level.

Two clusters were formed for roots/shoot dry mass ratio (Table 3). The cluster with the highest mean value $\left(0.35 \mathrm{~g} . \mathrm{g}^{-1}\right)$ was composed of most of the cultivars. The other one presented a mean of $0.27 \mathrm{~g} \mathrm{~g}^{-1}$ and consisted of cultivars Icatu Precoce 3282, Acaiá Cerrado MG 1474, Catucaí Vermelho 785/15, Catuaí Amarelo IAC 62, Oeiras MG 6851, and Caturra Vermelho.

No significant differences were detected for $\mathrm{N}$ Absorption Efficiency $(\mathrm{P} \leq 0.05)$ between the evaluated cultivars. However, most of the cultivars exhibited low $\mathrm{N}$ translocation efficiency (Table 3). Cultivars Icatu Vermelho IAC 4045, Icatu Precoce 3282, Acaiá Cerrado MG 1474, Oeiras MG 6851, and Caturra Vermelho stood out for presenting the highest $\mathrm{N}$ translocation efficiency to the shoot. Unlike San Ramon and São Bernardo, cultivars Obatã IAC 1669/20, Araponga MG1, and Tupi IAC 1669-33 presented higher rooting, N utilization, and biomass production efficiencies.

The clustering analysis using the UPGMA method classified the cultivars into five clusters with cophenetic correlation (CC) of 0.91 (Figure 1). Cluster I comprised cultivars Catuaí Amarelo IAC 62, Paraíso MG H 419-1, Caturra Amarelo, Catuaí Vermelho IAC 15, Rubi MG 1192, Araponga MG1, Topázio MG 1190, Oeiras MG 6851, Pau Brasil MG 1, Caturra Vermelho, and Catucaí 785/15 (Figure 1); cluster II consisted of cultivars San Ramon and São Bernardo; cluster III allocated cultivars Obatã IAC 1660/20, IPR 102, and IPR 103; cluster IV comprised only cultivar Tupi IAC 1669/33; and cluster V consisted of cultivars Icatu Vermelho IAC 4045, Icatu Precoce 3282, and Acaiá Cerrado MG 1474. 


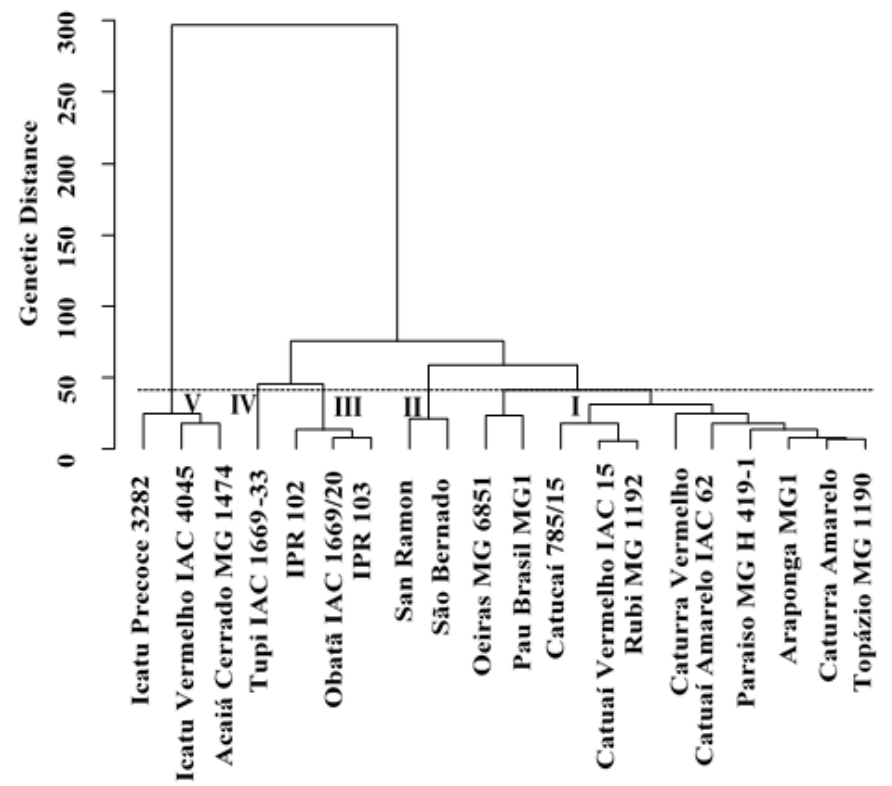

Figure 1. Dendrogram of the genetic dissimilarities between coffee cultivars cultivated in nutrient solution at low nitrogen concentration $\left(1.0 \mathrm{mmol} . \mathrm{L}^{-1}\right)$, obtained by the UPGMA method, based on 16 quantitative traits, using the Mahalanobis' generalized distance.

The clustering analysis by the Canonical Variables method, using the graphic dispersion (Figure 2), showed that the first two cumulative canonical variables (CV) explained $85.17 \%$ of the total variation. CV1 and CV2 were responsible for $68.16 \%$ and $17.01 \%$ of the total variation, respectively (Table 4). The five clusters formed by the canonical variables were the same as those generated by the UPGMA method.

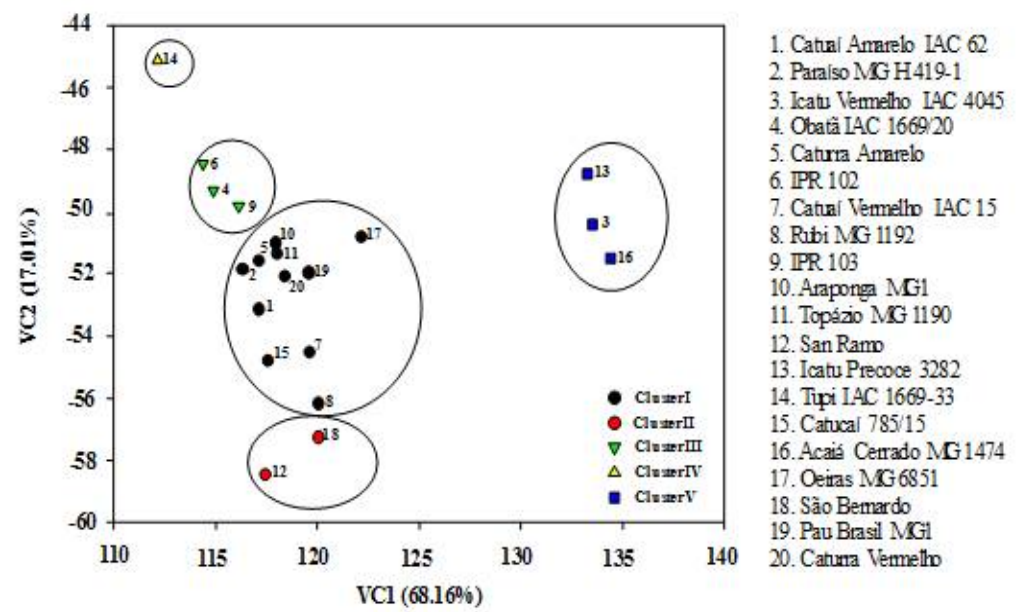

Figure 2. Graphic dispersion of the scores in relation to the representative axes of the canonical variables (CV1 and CV2) related to 16 traits evaluated for coffee cultivars cultivated in nutrient solution with a low nitrogen concentration (1.0 mmol.L $\mathrm{L}^{-1}$. 
Table 4. Accumulated variances $(\%)$ based on the canonical variables of the 16 traits evaluated for coffee cultivars $(\mathrm{CV})$ grown in nutrient solution at low nitrogen concentration $\left(1.0 \mathrm{mmol} . \mathrm{L}^{-1}\right)$.

\begin{tabular}{|c|c|c|c|c|c|c|c|c|c|c|c|}
\hline \multirow{2}{*}{$\begin{array}{l}\text { Var. } \\
\text { Accum. } \\
(\%)\end{array}$} & \multicolumn{11}{|c|}{$C V_{i}$} \\
\hline & $\begin{array}{r}\mathrm{CV}_{1} \\
68.16\end{array}$ & $\begin{array}{r}\mathrm{CV}_{2} \\
85.17\end{array}$ & $\begin{array}{r}\mathrm{CV}_{3} \\
90.27\end{array}$ & $\begin{array}{r}\mathrm{CV}_{4} \\
92.87\end{array}$ & $\begin{array}{r}\mathrm{CV}_{5} \\
94.93\end{array}$ & $\begin{array}{r}\mathrm{CV}_{6} \\
96.55\end{array}$ & $\begin{array}{r}\mathrm{CV}_{7} \\
97.77\end{array}$ & $\begin{array}{r}\mathrm{CV}_{8} \\
98.45\end{array}$ & $\begin{array}{r}\mathrm{CV}_{9} \\
98.96\end{array}$ & $\begin{array}{l}\ldots \\
\ldots \\
\ldots\end{array}$ & $\begin{array}{c}\mathrm{CV}_{16} \\
100.00\end{array}$ \\
\hline
\end{tabular}

The root, shoot, and total dry mass showed, in ascending order, the highest contributions for the genetic divergence among cultivars, with 17.44, 27.33, and 45.81\%, respectively, while the other 13 characteristics contributed with only $10.26 \%$ (Figure 3 ).

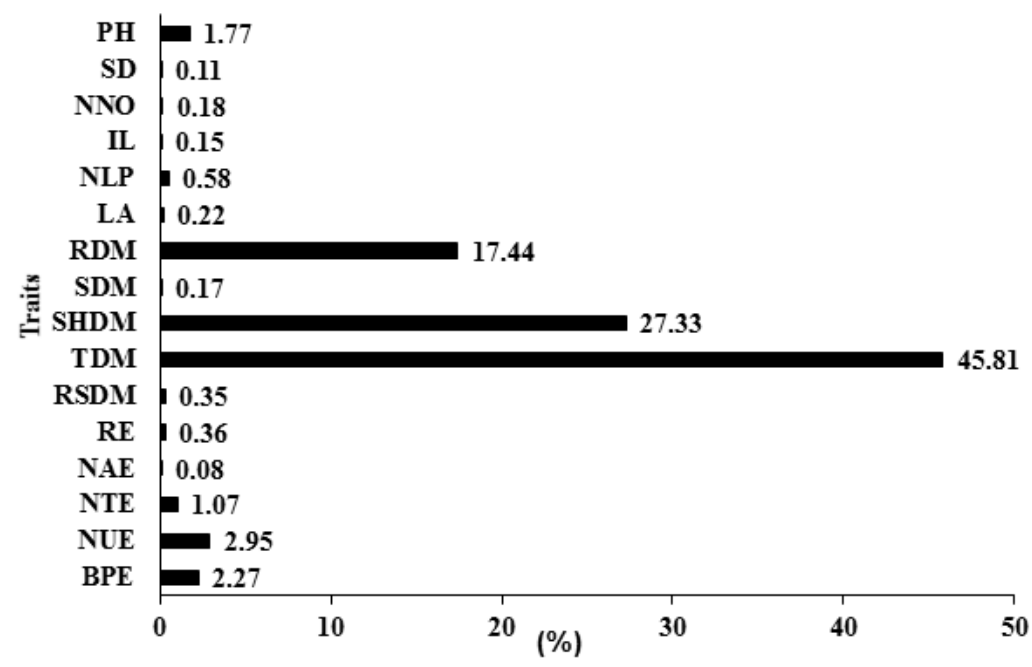

Figure 3. Relative contribution of the traits (\%), according to the methodology of Singh (1981), for coffee cultivars cultivated in nutrient solution at low nitrogen concentration $\left(1.0 \mathrm{mmol} . \mathrm{L}^{-1}\right)$. PH: plant height; SD: stem diameter; NNO: number of nodes; IL: internode length; NLP: number of leaf pairs; LA: leaf area; RDM: root dry matter; SDM: stem dry matter; SHDM: shoot dry matter; TDM: total dry matter; RSDM: root and shoot dry matter ratio; RE: rooting efficiency; NAE: nitrogen absorption efficiency; NTE: nitrogen translocation efficiency; NUE: nitrogen use efficiency; and BPE: biomass production efficiency.

\section{DISCUSSION}

At low $\mathrm{N}$ concentration, coffee cultivars presented genetic variability for the morphological traits and $\mathrm{N}$ utilization, rooting, translocation, and biomass production efficiencies, showing significant differences $(\mathrm{P} \leq 0.05)$ (Table 2 and 3$)$. This variability is the basis for genetic breeding programs to develop more efficient cultivars in nutrient utilization, which result from the better adaptation of these cultivars to environments under nutrient deficiency (Moura et al., 2016).

Cultivars Icatu Vermelho IAC 4045, Icatu Precoce 3282, and Acaiá Cerrado MG 1474 (Table 2) presented the highest means for plant height and internode length. This result can be attributed to the genetic factors that determine these traits (Carvalho, 2008). The opposite was found for cultivars San Ramon and São Bernardo; these being old and less genetically improved cultivars. These traits are relevant because they have a close positive correlation in production traits (Assis et al., 2014). 
Low $\mathrm{N}$ supply to coffee plants reduces leaf area due to the allocation of structural dry mass to other plant components, compromising the crop, since there is a relationship between grain yield and leaf production (Bote et al., 2018), as observed for the five cultivars shown above (Table 2). This behavior suggests that plants have a mechanism that causes allocation to other organs (probably storage structures) to the detriment of leaf expansion. Net photosynthesis, leaf $\mathrm{N}$ content, total protein content, and antioxidant enzymes are reduced in response to the low nutrient supply (Reis et al., 2015).

The greater number of nodes and leaf pairs detected in cultivars Icatu Vermelho IAC 4045, Acaiá Cerrado MG 1474, Catucaí Vermelho 785/15, Catuaí Vermelho IAC 15, Rubi MG 1192, Topázio MG 1190, and Caturra Vermelho (Table 2) indicates the possibility of higher yield since these traits are related to the appearance of primary plagiotropic branches and the production of secondary branches (Tomaz et al., 2005). Also, nitrogen availability may affect these traits since depending on the concentration, the fruiting zone on plagiotropic branches may change (Damatta et al., 2007).

The low $\mathrm{N}$ concentration in coffee plants may provide less synthesis of the hormone cytokinin, responsible for vegetative growth (Colodetti et al., 2014). This physiological disorder may lead to greater investment in plant stem growth when nitrogen is at low concentration. Therefore, most of the cultivars presented stem diameter values higher than the overall mean (Table 2), suggesting they were little affected by the $\mathrm{N}$ restriction in the culture medium. This trait is highly correlated with number of nodes of the first plagiotropic branch and plant vigor and is relevant for the discrimination of coffee genotypes (Teixeira et al., 2013).

The $\mathrm{N}$ concentration influences dry mass production in coffee plants due to the importance of this nutrient in the plant's metabolism (Gonthier et al., 2011). Thus, in the nitrogen-restricted cultivation, root, stem, shoot, and total dry mass were higher for cultivars Obatã IAC 1669/20, Araponga MG1, and Tupi IAC (Table 2 and 3). Also, cultivars Catucaí Vermelho 785/15, Obatã IAC 1669/20, IPR 102, IPR 103, Araponga MG 1, Topázio MG 1190, and Tupi IAC 1669-33 stood out for shoot and total dry mass (Table 3). The production of dry matter presents a close positive correlation with the production of grains (Assis et al., 2014).

Most of the cultivars with low $\mathrm{N}$ concentration invested more in root dry mass than shoot dry mass, leading to higher root/shoot dry mass ratio (Table 3). Cardoso (2010) observed that coffee cultivars submitted to the appropriate level of $\mathrm{N}\left(7,5 \mathrm{mmol} . \mathrm{L}^{-1}\right)$ in the solution had a mean root dry mass of $1.55 \mathrm{~g}$, which is about $25 \%$ lower than those cultivated with low $\mathrm{N}$, while average dry matter yield at the appropriate level was $7.85 \mathrm{~g}$, which is approximately $18 \%$ higher than at the low level. The greater root growth at low $\mathrm{N}$ availability can be attributed to the higher sucrose accumulation since the roots become the main user of this compound; however, this response varies among plant genotypes (Quan et al., 2016).

Genetic factors control nutrients absorption, transportation, and redistribution in plants (Martins et al., 2015). Nitrate $\left(\mathrm{NO}^{3-}\right)$ is the main form of $\mathrm{N}$ absorbed by plants. The increase in the number of lateral roots is an adaptative response due to the low availability of $\mathrm{NO}^{3-}$ (Kant, 2018). In this study, although no significant differences were detected for absorption efficiency, cultivars Icatu Vermelho IAC 4045, Icatu Precoce 3282, Acaiá Cerrado MG 1474, Oeiras MG 6851, and Caturra Vermelho had higher N translocation efficiency (Table 3), probably due to the higher interaction between the low and high 
affinity transporters, which ensured greater nutrient translocation. Moreover, the nutrient is more efficiently assimilated and incorporated into the shoot by these cultivars, even under nutrient stress (Krapp, 2015). Cultivars Obatã IAC 1669/20, Araponga MG1, and Tupi IAC 1669-33 showed higher rooting, $\mathrm{N}$ utilization, and biomass production efficiencies (Table 3). Similar results were also found when coffee was grown at appropriate levels of $\mathrm{N}$ (Cardoso, 2010). These cultivars exhibited similar behavior when evaluated at low potassium concentration (Moura et al., 2015), indicating that besides the ability of $\mathrm{K}$ utilization, they also have great $\mathrm{N}$ utilization efficiency. The determination of the indices of nutritional efficiency that depends on the dry mass and nutrient content shows dissimilar genotypes and cultivars of plant species (Baligar and Fageria, 2015).

Cultivars San Ramon and São Bernardo showed lower means for rooting, N utilization, and biomass production efficiencies (Table 3) due to the lower root dry mass production and lower total $\mathrm{N}$ concentration. This fact can be explained by the capacity of retaining greater nutrient content in the root vacuoles, reducing $\mathrm{N}$ translocation from the root to the photosynthetically active sites in the leaves (Amaral et al., 2012).

The cluster analyses by the UPGMA or canonical variables methods have been effective in discriminating cultivars of different coffee species (Pedrosa et al., 2013; Cao et al., 2014; Moura et al., 2015; Machado et al., 2017), as also observed in the present work. The UPGMA method presented a cophenetic correlation higher than $80 \%$, indicating a high representativity of the actual real distances between cultivars by the graphical representation of the dendrogram and higher reliability in the cluster formation (Saraçli et al., 2013). Similarly, the cluster analysis by the canonical variables method was satisfactory to discriminate the cultivars by the graphic representation since it presented accumulated values higher than $70 \%$ of the total variation (Rocha et al., 2009).

Both clustering methods formed five clusters. Cluster I was composed of most of the cultivars, which showed small size and susceptibility to rust (Figure 1 and 2); cluster II was composed of old cultivars, which presented low rooting, $\mathrm{N}$ utilization, and biomass production efficiencies; cluster III was formed by genetic materials called Sharchimor, which are resistant to rust and exhibited high shoot and total dry mass; cluster IV was made up of only one cultivar, which presented high rooting, $\mathrm{N}$ utilization, and biomass production efficiencies; and cluster $\mathrm{V}$ was composed of tall cultivars with high translocation efficiency.

The study on the relative importance of the traits assists the elimination of lessrelevant variables for genetic divergence (Cruz et al., 2012). Therefore, of the 16 traits evaluated, only total, root, and shoot dry mass productions were more relevant since they were responsible for $90.58 \%$ of the observed variability (Figure 3). Total dry mass contributed the most to the genetic divergence among the evaluated genotypes. Dry mass is the primary indicator of plant performance and is easily influenced by the $\mathrm{N}$ supply (Salamanca-Jimenez et al., 2016). This phenomenon occurs because this nutrient provides amino groups in amino acids, which are essential for protein formation and dry mass production (Maathuis, 2009).

The most divergent pairs of cultivar involved Icatu Precoce 3282, Icatu Vermelho IAC 4045, and Acaiá Cerrado MG 1474 (Figure 1). Conversely, the most similar combinations were obtained between cultivars Caturra Amarelo, Araponga MG 1, and Topázio MG 1190. For greater variability and genetic gain, genotypes from distinct clusters must be selected for crosses (Cruz et al., 2012) 
The analysis of means comparison and the clustering methods (UPGMA and Canonical Variables) demonstrated variability among the 20 cultivars at low nitrogen concentration. These results allowed selecting more divergent coffee cultivars for crosses that aim at $\mathrm{N}$ utilization efficient-cultivars, which will reduce the application of nitrogen fertilizers and coffee production costs. However, field studies should be conducted to consolidate this information since the research was performed in a greenhouse with a nutrient solution, instead of soil.

Genetic variability was detected among coffee cultivars grown at low nitrogen availability. Hybridization using combinations involving cultivars Icatu Precoce 3282, Icatu Vermelho IAC 4045, and Acaiá Cerrado MG 1474 are the most promising to obtain a segregating population or heterotic hybrids, aiming at higher nitrogen utilization efficiency.

\section{CONFLICTS OF INTEREST}

The authors declare no conflict of interest.

\section{ACKNOWLEDGMENTS}

The authors thank Paulo César de Lima (in memoriam) for his contribution in the experiments; the Consórcio Brasileiro de Pesquisa e Desenvolvimento do Café (CBP\&DCafé) for the financial support for this research; and the Conselho Nacional de Desenvolvimento Cientítico e Tecnológico $(\mathrm{CNPq})$, the Fundação de Amparo à Pesquisa do Estado de Minas Gerais (FAPEMIG), and the Fundação de Amparo à Pesquisa do Estado do Rio de Janeiro (FAPERJ) for the grants awarded to the authors.

\section{REFERENCES}

Amaral JFT, Martins LDB, Laviola G, Christo LF, et al. (2012). A differential response of physic nut genotypes regarding phosphorus absorption and utilization is evidenced by a comprehensive nutrition efficiency analysis. $J$. Agric Sci. 4: 164-173.

Assis GA, Guimarães RJ, Scalco MS, Colombo A, et al. (2014). Correlation between coffee plant growth and yield as function of water supply regime and planting density. Biosci. J. 30: 666-675.

Bailian L, Mckeand SE and Allen HL (1991). Genetic variation in nitrogen use efficiency of loblolly pine seedlings. Forest Sci. 2: 613-626.

Baligar VC and Fageria NK (2015). Nutrient use efficiency in plants: an overview. In: Nutrient use efficiency: from basics to advances (Rakshit A, Singh HB, Sen A, eds.). Springer, Dordrecht, The Netherlands.

Bote AD, Ayalew BF, Ocho LN, Anten PR, et al. (2018). Analysis of coffee (Coffea arabica L.) performance in relation to radiation levels and rates of nitrogen supply I. Vegetative growth, production and distribution of biomass and radiation use efficiency. Eur. J. Agron. 92: 115-122.

Bruno IP, Reichardt K, Bortolotto RP, Pinto VM, et al. (2015). Nitrogen balance and fertigation use efficiency in a field coffee crop. J. Plant Nutr. 38: 2055-2076.

Caixeta SL, Martinez HEP, Picanço MC, Cecon PR, et al. (2004). Leaf-miner attack in relation to nutrition and vigor of coffee-tree seedlings. Cienc. Rural 34: 1429-1435.

Cardoso PMR (2010). Biometric analysis of the nutritional efficiency for nitrogen in coffee (Coffea arabica L.). Master's thesis, Universidade Estadual do Norte Fluminense Darcy Ribeiro, Campos dos Goytacazes.

Cao EP, Constantino-Santos DM, Ramos LAP, Santos BS, et al. (2014). Molecular and morphological differentiation among Coffea (Rubiaceae) varieties grown in the farms of Cavite Province, Philippines. Phil. Sci. Lett. 7: 387-397.

Carvalho CHS (2008). Cultivares de café: origem, características e recomendações. Embrapa Café, Brasilia, Brazil.

Colodetti TV, Rodrigues WN, Martins LD and Tomaz MA (2014). Differential tolerance between genotypes of conilon coffee (Coffea canephora) to low availability of nitrogen in the soil. Aust. J. Crop Sci. 12: 1648-1657. 
CONAB (2018). Acompanhamento da safra brasileira de café. Companhia Nacional de Abastecimento [http://www.conab.gov.br/OlalaCMS/uploads/arquivos/18_01_24_17_34_27_cafe_janeiro2018.pdf]. Accessed 20 March 2018).

Cruz CD, Regazzi AJ and Carneiro PCS (2012). Modelos biométricos aplicados ao melhoramento genético. 4st edn. Editora Viçosa, Minas Gerais, Brazil.

Cruz CD (2013). Genes - a software package for analysis in experimental statistics and quantitative genetics. Acta Sci. 3: 271-276.

Damatta FM, Ronchi CP, Maestri M and Barros RS (2007). Ecophysiology of coffee growth and production. Braz. J. Plant Physiol. 4: 485-510.

EMBRAPA (2009). Manual de análises químicas de solos, plantas e fertilizantes. 2st edn. Embrapa Informação Tecnológica, Brasília, Brazil.

Fageria NK, Baligar VC and Li YC (2008). The role of nutrient efficient plants in improving crop yields in the twenty first century. J. Plant Nutr. 6: 1121-1157.

Falconer DS (1981). Introduction to quantitative genectics. $2^{\text {nd }}$ ed. London, England.

Gonthier DJ, Witter JD, Spongberg AL and Philpott SM (2011). Effect of nitrogen fertilization on caffeine production in coffee (Coffea arabica). Chemoecology 3: 123-130.

Hoagland DR and Arnon DI (1950). The water - culture method for growing plants without soil. Berkely: California Agricultural Experiment Station. PhD thesis, Universidad of California, United States.

Kant S (2018). Understanding nitrate uptake, signaling and remobilisation for improving plant nitrogen use efficiency. Semin. Cell. Dev. Biol. 74: 89-96.

Krapp A (2015). Plant nitrogen assimilation and its regulation: a complex puzzle with missing pieces. Curr. Opin. Plant Biol. 25: 115-122.

Machado CMS, Pimentel NS, Golynsk A, Ferreira A, et al. (2017). Genetic diversity among 16 genotypes of Coffea arabica in the Brazilian cerrado. Genet. Mol. Res. 3: 1-13.

Martins LD, Machado LS, Tomaz MA and Amaral JFT (2015). The nutritional efficiency of Coffea spp. A review. Afr. J. Biotechnol. 9: 728-734.

Maathuis FJ (2009). Physiological functions of mineral macronutrients. Curr. Opin. Plant Biol. 3: 250-258.

Moura WM, Soares YJB, Amaral Jr. AT, Gravina GA, et al. (2016). Biometric analysis of arabica coffee grown in low potassium nutrient solution under greenhouse conditions. Genet. Mol. Res. 3: 1-10.

Moura WDM, Soares YJB, Amaral Júnior ATD, Lima PCD, et al. (2015). Genetic diversity in Arabica coffee grown in potassium-constrained environment. Ciênc. agrotec. 1: 23-31.

Neto AP, Favarin JL, Dos Reis AR, Tezotto T, et al. (2015). Nitrogen metabolism in coffee plants in response to nitrogen supply by fertigation. Theor. Exp. Plant Physiol. 1: 41-50.

Pedrosa AW, Martinez HEP, Cruz CD, Damatta FM, et al. (2013). Characterizing zinc use efficiency in varieties of Arabica coffee. Acta Sci. Agron. 3: 343-348.

Pedrosa AW, Martinez HEP, Cruz CD, DaMatta FM, et al. (2013). Crescimento de cultivares de café em resposta a doses contrastantes de zinco. Coffee Sci. 3: 295-305.

Quan X, Qian Q, Ye Z, Zeng J, et al. (2016). Metabolic analysis of two contrasting wild barley genotypes grown hydroponically reveals adaptive strategies in response to low nitrogen stress. J. Plant Physiol. 206: 59-67.

R Development Core Team. (2006). R: a language and environment for statistical computing. R Foundation for Statistical Computing . [www.R-project.org]. Accessed 12 February 2018.

Reis AR, Favarin JL, Gallo LA, Moraes MM, et al. (2011). Influence of nitrogen fertilization on nickel accumulation and chemical composition of coffee plants during fruit development. J. Plant Nutr. 34: 1853-1866.

Reis AR, Favarin JL, Gratão PL, Capaldi FR, et al. (2015). Antioxidant metabolism in coffee (Coffea arabica L.) plants in response to nitrogen supply. Theor. Exp. Plant. Physiol. 3-4: 203-213.

Ribeiro JrJI (2001). Análises estatísticas no SAEG. Viçosa, Minas Gerais, Brazil.

Rocha MC, Gonçalves LSA, Correa FM, Rodrigues R, et al. (2009). Quantitative descriptors on determining genetic divergence among cherry tomato esaccessions. Ciênc. Rural 3: 664-670.

Saraçli S, Doğan N and Doğan İ (2013). Comparison of hierarchical cluster analysis methods by cophenetic correlation. J. Inequal. Appl. 203: 1-8.

Salamanca-Jimenez A, Doane TA and Horwath WR (2016). Performance of coffee seedlings as affected by soil moisture and nitrogen application. In: Advances in Agronomy (Sparks D, eds.). Academic Press, Cambridge, United States.

Siddiqi MY and Glass ADM (1981). Utilization index: a modified approach to the estimation and comparison of nutrient utilization efficiency in plants. J. Plant Nutr. 3: 289-302.

Singh D (1981). The relative importance of characters affecting genetic divergence. Indian J. Genet. Pl. Br. 41: 237-245.

Teixeira AL, Gonçalvez FMA, Rezende JC, Rocha RB, et al. (2013). Análise de componentes principais em caracteres morfológicos de café arábica em estádio juvenil. Coffee Sci. 2: 205-210.

Tomaz MA, Martinez HEP, Cruz CD, Ferrari RB, et al. (2008). Diferenças genéticas na eficiência de absorção, na translocação e na utilização de K, Ca e Mg em mudas enxertadas de cafeeiro. Ciênc. Rural. 6: 1540-1546.

Tomaz MA, Sakiyama NS, Martinez HEP, Cruz C, et al. (2005). Porta-enxertos afetando o desenvolvimento de plantas de Coffea arabica L. Ciênc. Rural. 3: 124-132.

Genetics and Molecular Research 18 (2): gmr18175

CFUNPEC-RP www.funpecrp.com.br 